\title{
ESCRITAS DE OUVIDO NA LITERATURA BRASILEIRA $^{1}$
}

\author{
MaríLIa LIBRANDI-ROCHA \\ Stanford University
}

\section{Resumo}

Este texto propõe que no coração da literatura brasileira encontra-se o pulsar de uma escrita auditiva, elaborada por autores que "escrevem de ouvido". O objetivo é conceituar o termo "escrita de ouvido", e descrever a forma que assume na prosa de ficção, em especial no romance. Machado de Assis, Clarice Lispector e Guimarães Rosa são os escritores centrais dessa pesquisa, que também se aplica a outros escritores-chave como Oswald de Andrade, Mário de Andrade e Graciliano Ramos. Pensa-se pois o ouvido como um terceiro termo para além da dicotomia entre a fala e a escrita, o romance, como um espaço de escuta, e a autoria, como um lugar de recepção mais do que de producão. Busca-se assim contribuir para uma poética da ressonância e uma história aural da literatura escrita em português com acentos multilíngues.

\section{Abstract}

If we listen closely, we can hear the pulse of an auditory writing at work in several authors at the heart of Brazilian literature. The aim of this text is to develop the concept of "Writing by Ear", and the form it takes in fictional prose, especially in novels. Machado de Assis, Clarice Lispector, and Guimarães Rosa are the central authors of this research also applicable to other key authors of prose fiction, including Oswald de Andrade, Mário de Andrade, and Graciliano Ramos. This text thinks the ear as a third term beyond the dyad speech and writing, the novel, as a space of listening, and authorship, as a place of reception more than a place of production. It hopes to contribute to a poetics of resonance and an aural history of literature written in Portuguese with multilingual accents.

\section{Palavras-chave} Escuta; Clarice Lispector; Oswald de Andrade; Machado de Assis

Keywords

Listening;

Clarice

Lispector;

Oswald de

Andrade;

Machado de

Assis 
Ouço a música antiga de palavras e palavras, sim, é assim.

Clarice Lispector

É só ter alma de ouvir e coração de escutar

Intróito

Caetano Veloso ${ }^{2}$

Este texto propõe que no coração da literatura brasileira encontra-se o pulsar de uma escrita auditiva. A complexa aproximação entre palavras escritas e o sentido da audição foi sugerida por Clarice Lispector na novela $A$ hora da estrela, publicada dois meses antes de sua morte em 1977: "E a pergunta é: como escrevo? Verifico que escrevo de ouvido assim como aprendi inglês e francês de ouvido". ${ }^{3}$ Nesses mesmos anos, Augusto de Campos, escreve um poema denominado "O pulsar", que se apresenta como um telegrama estrelar. ${ }^{4}$ As palavras do poema aparecem em branco sobre um fundo preto com duas letras transformadas em desenhos: a vogal "o" é um pequeno círculo branco solar, e a vogal "e" é substituída pela imagem de uma estrela, atuando como pontos luminosos. No poema, solicita-se ao observador/leitor que "abra a janela" e veja o "pulsar quase mudo" de uma mensagem exposta no céu/na página. Esse pulsar foi imediatamente ouvido por Caetano Veloso, que em 1975 musicou o poema acentuando a conexão entre escrita, visão e audição, em uma colaboração importante dentro do programa "verbivocovisual" dos "poetas de campos e espaços". ${ }^{5}$ No contexto deste texto, $A$ hora da estrela de Lispector, novela escrita de ouvido, e as estrelas do poema de Campos com seu pulsar quase mudo ressoam juntas como um recado a ser decifrado: "onde quer quer você esteja/ em marte ou eldorado/ abra a janela e veja/ o pulsar quase mudo/ abraço de anos-luz/ que nenhum sol aquece/ e o o(e)co escuro esquece". O final sem sol, com o apagar do poema e, na novela de Lispector, com a morte da personagem Macabéa, coincide com a hora da estrela que, no escuro, brilha, e com a palavra escrita que, silenciosa, pulsa. Anos depois, na contracapa de Despoesia, de 1994, Augusto de Campos volta a reafirma o pulsar em sua relação com a ação poética: "A flor flore./ A aranha tece./ O poeta poeta./ Quer o vejam quer não, ele pulsa./ O pulsar quase mudo". ${ }^{6} \mathrm{O}$ mesmo pulsar quase mudo é afirmado por Lispector em relação ao sentido de sua escrita sobre a personagem Macabéa: "Morta, os sinos badalavam mas sem que seus bronzes lhes dessem som. Agora entendo essa história. Ela é a iminência que há nos sinos que quase-quase badalam". ${ }^{7}$ A mesma qualidade de um pulsar quase mudo reaparece na descrição de outra personagem clariceana: "Ângela é o tremor vibrante de uma corda tensa de harpa depois que é tocada: ela fica no ar ainda se dizendo, dizendo - até que a vibração morra espraiando-se em espumas pelas areias. Depois - silêncio e estrelas". ${ }^{8}$

Aproximar a escrita de ouvido de Lispector ao pulsar quase mudo de Augusto de Campos permite descrever uma qualidade distintiva da literatura brasileira: seu ouvido aguçado, ou em outras palavras, a proximidade de sua escrita com a captação de timbres e de nuances, acentuados no interior de uma cultura em que a oralidade e a musicalidade predominam. Este texto, focando-se especificamente na presença do ouvido na escrita, propõe pensar um sentido menos explorado nas relações entre oralidade, música e literatura no Brasil, ${ }^{9}$ integrando-se a uma corrente teórica que vem pensando, desde pelo menos Paul Zumthor, a 
importância da voz e da escuta no texto escrito. ${ }^{10}$ Minha sugestão é pensar o texto ficcional como se fosse uma caixa de música que pulsa e reverbera o vivido e o pensado em uma forma escrita, que ressoa novamente a cada leitura ao mesmo tempo em que se propaga no futuro cada vez que é reaberta. Essa sugestão coincide com a proposta defendida por Wai Chee Dimock de pensar a literatura a partir do conceito de ressonância. ${ }^{11}$ Dimock contesta a primazia da visão no pensamento filosófico, e defende a prevalência da audição para redefinir o texto literário como um objeto com uma ontologia instável, que se modifica com o tempo e com as leituras que recebe.

Com o termo "escritas de ouvido" intento fornecer um modelo teórico simplificado passível de ser aplicado a diferentes escritores da literatura no Brasil. ${ }^{12}$ Em linhas gerais, a escrita de ouvido pode ser definida a partir de três vetores principais: um impulso musical não mimético que realça a qualidade dominante da escrita literária; ${ }^{13}$ um multilingualismo sonoro que produz a literatura como uma língua franca cosmopolita; e um espaço de escuta que se situa além das dicotomias letrado/não letrado; literatura/culturas orais; fala/escrita. Neste último aspecto, importa saber o que uma escrita que prima pela audição quer dizer em termos éticos e políticos. Sugiro que se trata de uma ética de abrir os ouvidos para ouvir a voz, os sons, os ruídos, dos grupos que se situam fora do letramento oficial, e que se relacionaria com um engajamento literário dominante em ex-colônias nas quais uma cultura oral e musical predominante será transposta para a escrita literária, afetando-a.

No campo dos estudos do romance, a escrita de ouvido assume uma forma vinculada a três procedimentos: 1) a duplicacão ou multiplicação de vozes autorais, quando o escritor deixa de ser apenas aquele que escreve e passa a ser aquele que ouve; 2) o estabelecimento de um modelo conversacional, explícito nos constantes apelos aos leitores; 3) e a exibição de uma obra in progress, com a defesa da improvisação como método (efetivo ou fingido) de composição literária, como se o livro se escrevesse aqui e agora no momento mesmo em que estaria sendo lido. Nos três casos, trata-se de procedimentos metaficcionais, que instauram um paradigma musical, performático e teatral na escrita em prosa. Em paralelo com a noção de escrita de ouvido, sugiro chamar esse modelo de "romance em eco" ou "romance ecoacústico". Minha hipótese é a de que esse modelo coincidiria com a prosa moderna na linha aberta por Machado de Assis nas últimas décadas do século XIX, reaparecendo com diferença nas obras de vários outros ficcionistas modernos: Oswald de Andrade, Mário de Andrade, Graciliano Ramos, Guimarães Rosa e Clarice Lispector. Esse modelo seria radicalizado a partir dos anos 1970, seja na obra em prosa de Hilda Hilst, como em Fluxo-floema, de 1970, seja a partir de Água viva (1973), de Lispector, seja em obras como Catatau (1975) de Paulo Leminski, quando, a partir de então, outras dicções irão proliferar no campo do contemporâneo. ${ }^{14}$

\section{Contribuição para uma história aural da literatura no Brasil. Zona de contato}

A literatura produzida no Brasil é tanto o resultado de encontros e desencontros coloniais como é a escrita de uma língua que se institui na zona de contato do português europeu com as línguas ameríndias, sobretudo a "língua geral" falada no Brasil por cerca de duzentos anos, assim como o nheengatu na região amazônica, o guarani e o espanhol na 
América meridional, as línguas africanas da família Banto, e, a partir do século XIX, as línguas dos imigrantes espanhóis, catalães, judeus, sírios, libaneses, italianos, japoneses, que se estabeleceram no Brasil, para citar apenas alguns desses grupos.

Assim, para uma história da escrita de ouvido moderna no Brasil é preciso retornar não apenas ao momento de independência e constituição do Brasil como nação no século XIX, mas retornar ao passado colonial da América Luso-Afro-Hispano-Indígena-Brasílica, que ecoa na prosa de ficção escrita de ouvido, e que se configura como uma resposta pós-colonial aos primeiros contatos e à história da colonização. Nesse aspecto, parece-me importante retomar o termo "zonas de contato" proposto por Mary Louise Pratt, "para referir ao espaço dos encontros coloniais, [...] em geral envolvendo condições de coerção, desigualdade radical, e conflitos intratáveis". ${ }^{15} \mathrm{Na}$ introdução de seu livro, Imperial Eyes, intitulada, "Criticism in the contact zone", Pratt explica o uso do termo:

\begin{abstract}
Tomo aqui de empréstimo o termo "contato" de seu uso na linguística, em que o termo contato remete a línguas improvisadas desenvolvidas entre falantes de diversas línguas nativas que precisam comunicar-se uns com os outros de modo consistente, habitualmente em contextos comerciais. Tais línguas começam como pidgins, e são chamadas crioulas quando acabam por ter seus próprios falantes nativos. Como as sociedades da zona de contato, tais linguagens, são comumente vistas como caóticas, bárbaras, falhas de estrutura (Ron Carter sugeriu o termo "literaturas de contato" para se referir às literaturas escritas em linguagens europeias fora da Europa). ${ }^{16}$
\end{abstract}

Ao estudar as narrativas de viagem produzidas pelo observador masculino europeu, que olha para possuir e colonizar ("Seeing Man"), Pratt analisa a "zona de contato" em relação ao campo visual. No nosso caso, a escrita de ouvido pode ser entendida como a sua contraparte sonora e auditiva. Assim, em contraste com o termo "olhos imperiais" ("Imperial Eyes"), precisamos pensar os "ouvidos nativos". O termo "ouvidos nativos" remete certamente aos Ameríndios e aos primeiros contatos durante a colonização como veremos adiante, mas remete também à audição como o primeiro sentido vinculado à gestação, ao corpo materno e ao momento pré-verbal. Como explica David Toop, no momento gestacional, o primeiro sentido a se desenvolver é o auditivo e não o visual: "[q]uatro meses e meio após a concepção nós começamos a ouvir. Esse é o primeiro de nossos sentidos a funcionar: a audição domina a vida amniótica, embora após o nascimento sua importância seja suplantada pela visão". ${ }^{17}$ Assim também, no primeiro volume de sua trilogia, Esferas, Peter Sloterdjik debruça-se sobre a intimidade da experiência acústica que precede a separação do "Eu" e do outro, e corresponde às "micro-esferas" do que ele denomina o "interior da mãe absoluta", a placenta dual, e o espaço ressoante da voz materna ${ }^{18}$. Assim, a escrita de ouvido necessariamente envolve um pensamento sobre a ficção como campo de audicão próximo da esfera materna. Por ora, sem poder desenvolver melhor esse tópico, gostaria de reter o fato de que se o "Seeing man" (estudado por Pratt) ocupa o lugar patriarcal histórico colonizador, a voz e o corpo materno, que também se confunde com a imagem símbolo da "mãe natureza", é onde uma escrita de ouvido encontra seu lugar ${ }^{19}$

\title{
Zona de tradução
}

Pensar a escrita de ouvido significa então contribuir para uma história literária aural, focada na transmissão e nas influências auditivas na escrita. Nessa história aural, a tradução 
ocupa um papel de destaque. Por isso, ao termo "zona de contato" adiciono o termo "zona de traducão" proposto por Emily Apter ${ }^{20}$ em um estudo que repensa a tradução sobretudo em contextos de guerra e disputa de poder. No caso da escrita de ouvido, o foco volta-se mais para a incorporação amorosa de linguas estrangeiras no português brasileiro, ou de linguas nativas ecoando nos textos escritos. No caso, chamo a atenção para o fato de que, em português, a palavra "zona" adquire dois outros significados idiomáticos ausentes no inglês, "zone". Além de remeter a uma área de troca e de contatos, "zona" em português refere a um local em desordem (como na expressão "esse quarto está uma zona"), e remete também ao termo usado para designar uma área de prostituição (como na expressão "eu vou para a zona"). Assim, em relação à escrita de ouvido, "zona" de contato e de tradução deve incluir esses três significados: o cruzamento linguístico via tradução, uma certa confusão sonora na escrita através do uso de trocadilhos, chistes e outros jogos acústicos, e uma esfera erotizada especificamente associada aos ouvidos. Nesse último aspecto, a distância dos olhos em relação aos objetos de observação e de desejo é substituída pela proximidade do ataque sonoro. Como diz Jean-Luc Nancy, os sons nos atingem sem que possamos fechar os ouvidos. ${ }^{21}$ Além disso, o auditivo implica uma zona de contato na qual é a posição receptiva e não a produtora que vem à tona em primeiro lugar. Por isso também, a dominância da visão no pensamento teórico e filosófico contrasta com a passividade associada à audição. Essa dualidade vai se refletir na distinção tradicional de gênero entre o masculino e o feminino.

\section{Os "línguas", Padre Vieira e Oswald de Andrade}

A presença e a importância da audição no Brasil têm uma longa história, que, a meu ver, remonta aos línguas, aqueles indivíduos assim chamados porque postos entre as línguas indígenas e o português da catequese. Fossem índios treinados pelos padres ou padres que aprendiam os idiomas indígenas, os línguas aprendiam "de oitiva". ${ }^{22} \mathrm{Na}$ colonização, o foco era incluir a fé cristã na fala índia para assim eliminar os "bárbaros", sua vida, sua língua, seu pensar, e transformá-los em "catecúmenos," o mesmo ocorrendo em relação aos negros escravos, tidos por "boçais" (incapazes de pronunciar bem a língua portuguesa). O seguinte comentário de Antônio Vieira, em sermão de 1657, explicita o processo de uma relação colonizadora orientada pela audição:

\footnotetext{
Por vezes me aconteceu estar com o ouvido aplicado à boca do bárbaro, e ainda do intérprete, sem poder distinguir as sílabas, nem perceber as vogais ou consoantes de que se formavam, equivocando-se a mesma letra com duas ou três semelhantes, [...] outras tão duras e escabrosas, outras tão interiores e escuras, e mais afogadas na garganta que pronunciadas na língua; outras tão curtas e subidas, outras tão estendidas e multiplicadas, que não percebem os ouvidos mais que a confusão, sendo certo, em todo o rigor, que as tais línguas não se ouvem, pois se não ouve delas mais que o sonido, e não palavras desarticuladas e humanas. ${ }^{23}$
}

Os ouvidos missionários não podem entender os significados das palavras pronunciadas, mas apenas a "confusão" sonora de línguas "escuras" às quais faltaria a luz da razão divina. Usado para incentivar e justificar a catequese, o argumento, no entanto, revela mais da incapacidade dos missionários em ouvir, isto é, sua dificuldade em fazer sentido de línguas estrangeiras cujo acesso não é dado pela leitura apenas pela audição. Como diz Alcir Pécora em comentário a essa passagem, cabia aos missionários, segundo o sermão de Vieira, a tarefa de reduzir a língua indígena a um "audível inteligível". ${ }^{24}$ 
A reversão ética-política-estética desse movimento de escuta será a ponta de lança da luta literária do escritor que vai explicitamente situar-se "[c]ontra o Padre Vieira" ao denunciar a sua "lábia": ${ }^{25}$ Oswald de Andrade. Ouvido atinado com os "erros de português", Oswaldo ou Oswâld acentua uma ética-estética da audição que reverte o processo da catequese: "O homem europeu falou demais. [...] É preciso ouvir o homem nu". ${ }^{26}$ Para uma história aural na literatura brasileira é fundamental recuperar e repensar tanto o matriarcado segundo a proposta oswaldiana, como realçar a importância da audição no projeto antropofágico. Em uma de suas crônicas, parte da série, não por acaso, intitulada Telefonema, Oswald acentua a relação da boca antropofágica com a escuta: "O movimento aqui em São Paulo desenvolvido com o nome de 'Antropofagia', nunca excluiu as conquistas técnicas da cívilização nem os sonhos do momento social. Mas fazia escutar a voz bárbara dos trópicos". ${ }^{27}$ Escreve-se, então, contra os processos de silenciamento das "vozes bárbaras" na escrita, e para dinamizar as potências guardadas em secreto silêncio nas letras, mas audíveis nas ruas, nos sons, nos batuques, nos sambas e ritmos das práticas religioso-festivas. Será por essa reversão, que alguns dos melhores letrados do Brasil des-leem (ou leem pelo avesso) o legado da colonização ao incorporá-lo às vozes nativas. Nos termos modernos da narrativa de ficção, no romance e suas variantes como a novela, ou a prosa poética o que veremos é uma ação escritural que opera em vista de uma des-domestificação da oralidade, e que a inclui para barbarizar a escrita e romper com o emudecimento crescente da voz índia, as sertanejas, e outras: essa será a utopia política anárquica da melhor prosa de ficção produzida na América Latina.

\section{O H da questão (ouve/houve; estória/história)}

Em 1926, no primeiro prefácio a Serafim Ponte Grande (1933), Oswald de Andrade anuncia, no seu modo aforismático de escrita, um procedimento chave na narrativa de ficção no Brasil: "A gente escreve o que ouve, nunca o que houve". ${ }^{28}$ No entanto, para perceber a jocosidade da frase é preciso lê-la por escrito, pois se o som é o mesmo, "ouve/(h)ouve", os verbos são distintos, ouvir/ haver. No caso, uma mesma pronúncia remete, na leitura, a dois significados distintos, em um procedimento semelhante ao que será utilizado por Jacques Derrida quando cria os termos "animots" (mesmo som de animaux) e "differance" (soando o mesmo que différence). Assim, a frase de Oswald precisa ser lida para ser entendida (ouvida), estabelecendo uma relação intrínseca entre a esfera sonora e os textos impressos mudos.

Quando o enfant terrible da burguesia paulista do café anuncia que escreve o que ouve e não o que houve, ele está propondo o mesmo jogo sonoro que fará quando enuncia o princípio filosófico ameríndio-brasílico baseado em uma recriacão sonora do verso shakesperiano: "tupi or not tupi: that is the question". Outra passagem do "Manifesto antropófago", muito provavelmente fruto de um equívoco tipográfico muito bem achado ao juntar oráculo e auricular, confirma a importância crucial do universo sonoro no Brasil: "Só podemos atender ao mundo orecular". Oswald propõe assim que a questão brasileira de inserção no debate internacional e de incorporação da tradição passa por um jogo sonoro que é jocoso, satírico e paródico, através do qual outras possiblidades se inscrevem. ${ }^{29}$

Através desse princípio sonoro guiando a incorporação do outro e da tradição, joga-se com o dilema fundamental entre cópia e original. Contestando a estética realista e naturalista como cópia submissa do que vem de fora, Oswald propõe assim uma mimesis baseada na 
audição como uma contribuição de sua filosofia da devoração antropofágica que é preciso compreender melhor e analisar. Voltando ao "A gente escreve o que ouve nunca o que houve", de modo muito agudo (ou grave), Oswald está anunciando uma diferença crucial entra a escrita de invenção, a escrita literária de "descoberta e transposição", ${ }^{30}$ e a escrita da história, dedicada a uma compreensão posterior do que houve. Ou seja, ele estabelece uma diferença entre a percepção auditiva (que seria então característica da escrita ficcional) e a representação histórica.

Por que a ficção estaria mais próxima da escuta do que outros tipos de narrativa? A resposta pode variar de autor para autor. João Guimarães Rosa, por exemplo, já definido por Ana Luiza Martins Costa como o escritor por excelência de um "mundo escutado", 31 assim enunciou em um dos prefácios de seu livro Tutaméia (1967): “A estória não quer ser história. A estória, em rigor, deve ser contra a história. A estória, às vezes, quer-se um pouco parecida à anedota". ${ }^{32}$ Para Rosa, estórias devem estar próximas da anedota e do chiste para combater os pesadelos da história. Essa frase era também um modo de rebater as críticas sobre sua obra não ser politicamente engajada, ao sugerir que para a prosa de ficção alterar as relações políticas e sociais entre a população iletrada e rural e o cidadão letrado e urbano seria necessário nao apenas representação literária como cópia de narrativas históricas, mas seria preciso alterar as políticas de enunciação. Como Rosa disse em entrevista, "somente renovando a língua pode-se renovar o mundo". 33

Importa por fim ressaltar que tanto na frase de Oswald, no prefácio de sua novela, como no prefácio de Rosa, em Tutaméia, encontramos a mesma diferença entre ficção (estória) e história baseada na presença ou na ausência da silenciosa letra h (em ouve/houve; estoria/história), uma letra que nao tem sonoridade fonética no português e apenas age como aspiração e respiração (um suspiro). Estabelece-se, assim, uma diferença entre os discursos da história e os "discursos do ouvido" para lembrar a expressão de Jacques Derrida em seu texto "Tímpano". 34

De modo semelhante, escreve Clarice Lispector, autora aliás de um livro chamado Um sopro de vida: Pulsações: "(Vai ser difícil escrever esta história. ... Os fatos são sonoros mas entre os fatos há um sussurro. É o sussurro que me impressiona)" ${ }^{35}$ Como pode o sussuro ser escrito senão pela criação ficcional, isto é, senão através de um texto que busca imprimir rítmica e onomato-poeticamente o que está atrás do pensamento (título anterior do livro Água viva), ou o que está aquém ou além da linguagem, como as sensações, pulsações, reverberações e timbres?

\section{Clarice Lispector e a escrita de ouvido}

A expressão "escrevo de ouvido", que aparece em $A$ hora da estrela, é a versão ficcional de uma anotação pessoal que Claire Varin encontrou em um dos cadernos de Lispector, e que se tornou o ponto de partida de seu estudo Langues de feu: "Vivo 'de ouvido'. Vivo de ter ouvido falar". ${ }^{36}$ Talvez não tenha sido por acaso: foi preciso que a canadense Claire, ao vir ao Brasil para estudar Clarice, e aprender o português, captasse aquilo que permanecia, de certo modo, latente para ouvidos brasileiros: a importância da voz e da audição na sua escrita ou, segundo a bela expressão de Varin, a "volúpia da voz antes de toda apreensão". ${ }^{37}$ Seu estudo abriu assim as portas para novos trabalhos na mesma direção, como este devotado 
especificamente à compreensão do termo "escrevo de ouvido" (ao qual Varin não se dedica) e suas possíveis aplicações em sentido amplo.

O que quererá dizer "escrevo de ouvido"? Tocar uma música de ouvido significa reproduzir com o instrumento o som que se ouve sem ter a partitura diante dos olhos, assim como aprender uma língua de ouvido significa ouvir os sons das palavras e apreender seus significados e a estrutura gramatical da língua em um processo de imersão mais do que de leitura e estudo prévios. Em ambos os casos, trata-se de um método que avança por acerto e erro, em um processo de imersão antes inconsciente que consciente, que procede às cegas. Isso me permite aproximar o "escrevo de ouvido" de Lispector ao "Darkling I Listen" ("Às escuras escuto") de John Keats ("Ode to a Nightingale") que, por sua vez, remete a uma outra importante expressão de Lispector, reveladora de seu método de escrita: "a procura da palavra no escuro". ${ }^{38}$ A cegueira, então, outro aspecto fundamental na escrita visionária de Lispector, ${ }^{39}$ acentua o sentido da audição, tornando-o mais preciso para a captação de timbres e de nuances, como diz o narrador de $A$ hora da estrela: "As palavras são sons transfundidos de sombras que se entrecruzam desiguais, estalactites, renda, música transfigurada de órgão. Mal ouso clamar palavras a esse rede vibrante e rica, mórbida e obscura tendo como contratom o baixo grosso da dor. Alegro com brio".40

A "escrita de ouvido" demanda, aliás, leitores aptos a "ouvir" um texto escrito, de modo a captar precisamente aquilo que passa entre as linhas, como a forma e o desenho de uma entonação, de um tom ou de um timbre. Nessa expressão, "escrevo de ouvido", que se assemelha pois a uma autodescoberta, Clarice Lispector abre as portas para um mundo ainda pouco explorado no universo da escrita literária: o estudo das propriedades acústicas da escrita, presentes tanto no momento da criação ficcional, quando o escritor "ouve" vozes e as inscreve, como na leitura silenciosa, quando um mundo imaginário é despertado pela vibração sonora e imagética das palavras.

Um outro elemento, a questão do estrangeiro, é importante para definirmos a escrita de ouvido. Clarice diz escrever de ouvido como quem aprende uma língua estrangeira: "Verifico que escrevo de ouvido assim como aprendi inglês e francês de ouvido". ${ }^{41}$ Como filha de pais judeus imigrantes falando ídiche, Clarice nasceu no meio do caminho, isto é, durante a viagem que sua família empreendeu da Rússia para o Brasil em 1920, fugindo da crescente perseguição aos judeus. ${ }^{42} \mathrm{O}$ português, língua que ela aprendeu de ouvido quando chegou ao Brasil com um ano de idade, é, pois, como o inglês e francês, sua língua não materna. ${ }^{43}$ Essa peculiaridade faz de Lispector um caso exemplar do escritor que escreve em sua língua como um estrangeiro, ${ }^{44} \mathrm{o}$ que a torna uma escritora especialmente hábil a ouvir nuances, timbres e entonações (matéria que antecede a compreensão semântica): "a palavra tem de se parecer com a palavra, instrumento meu. Ou não sou um escritor? Na verdade sou mais ator porque, com apenas um modo de pontuar, faço malabarismos de entonação, obrigo o respirar alheio a me acompanhar o texto". ${ }^{45}$ Fazer "malabarismos de entonação" é o modo de quem escreve de ouvido como um estrangeiro que repete mentalmente a sonoridade da língua que ouve para apreender seus trejeitos e acentos. A pontuação do texto de Lispector quer, então, capturar a entonação, por isso a dificuldade de escrever.

"Escrevo de ouvido" quer, então, dizer que se escreve com a lingua pré-consciente, com a língua que se ouve antes que se entendam seus significados, com a língua que é significante antes de ser significado; com a língua que é antes de tudo som, tom, nuance, e vibração. Esse 
fato é confirmado pelos leitores de Lispector que sabem que sua escrita atua como a captação constante de uma vibração, como um dizer que quer inscrever o não dito. Como escritora, Lispector não se contenta com seu material, a palavra escolhida e efetivamente usada; como escritora, ela quer que seu leitor leia, ou melhor, ouça, na palavra escrita todas aquelas que ficaram como virtualidades não realizadas, como se fosse possível escrever, não segundo a linha sintagmática, mas apenas seguindo a linha do paradigma. A escrita de Lispector é, assim, uma escrita em suspenso, que paira, como o silêncio que a gente não ouve e nem por isso deixa de estar presente. Por isso, cores (visão) e som (audição) são seus principais paradigmas. Por isso também, ler Clarice pode ser uma experiência tão difícil e ao mesmo tempo prazerosa. Suas palavras nos atingem antes como sons, com o corpo, e atingem regiões inesperadas, como a música a quem o livro $A$ hora da estrela é dedicado. ${ }^{46}$ Por "escrevo de ouvido" em Lispector entende-se, então, uma técnica sensória e intuitiva de uma escrita que segue o impulso rítmico e sonoro assim como os ecos do inconsciente antes de ser dominada pela elaboração lógica e semântica. Minha suposição é a de que no contexto da literatura brasileira, a escrita de ouvido alia-se ao improviso, entendido como a captação de uma impressão o mais próxima possível da expressão.

\section{Improvisação}

Escolho definir improvisação através da equação impressão = expressão. Essa equação significa que a improvisação almeja criar uma expressão simbólica o mais próxima possível da impressão sensorial, como se fosse possível ao corpo não se distinguir do seu entorno. Clarice Lispector é também a fonte dessa definição. Falando sobre a personagem Lucrécia do romance A cidade sitiada, diz o narrador: "Nela e em um cavalo a impressão era a expressão". ${ }^{47}$ Essa frase foi posteriormente explicada em uma carta, como um modo de ser e estar que remete

\footnotetext{
a essa espécie de integridade espiritual de um cavalo, que não "reparte" o que vê, que não tem uma "visão vocabular" ou mental das coisas, que não sente a necessidade de completar a impressão com a expressão - cavalo em que há o milagre de a impressão ser total - tão real - que nele a impressão já é a expressão. 48
}

A comparação com um cavalo não deve surpreender. Lispector afirmou certa vez que gostaria de ter nascido cavalo, e é justamente a comparação com um cavalo que define o modo como ela descreve sua relação com a língua portuguesa, ou melhor, com a língua brasileira, que ela considerava como uma língua em estado de formação, uma língua a ser trabalhada pelo pensamento para gerar sutilezas; uma língua-animal a ser domada:

Esta é uma confissão de amor: amo a língua portuguesa. Ela não é fácil. Não é maleável. [...] Às vezes ela reage diante de um pensamento mais complicado. Às vezes se assusta com o imprevisível de uma frase. Eu gosto de manejá-la - como gostava de estar montada num cavalo e guiá-lo pelas rédeas, às vezes lentamente, às vezes a galope. ${ }^{49}$

Minha sugestão é, pois, a de que a escrita de ouvido alia-se a um método de "improviso" para alcançar um estado ideal de integração entre o exterior e o interior, entre as palavras e a coisa para captação da matéria viva e irrepetível. Como sabemos, a improvisação suspende ou elimina o pensar ponderado, medido e controlado para atuar como uma reação a mais imediata possível aos estímulos presentes, e seu resultado é tanto melhor quanto menos programado for; 
quanto mais o agente deixar-se levar pelo estímulo do momento. É o que ocorre com o improvisar em uma apresentação musical ou teatral: o que conta é a reação imediata ao que ocorre aqui e agora. Essa reação certamente inclui o saber prévio, o treinamento e o conhecimento, mas, na ação do improviso, todo esse repertório tem de ser como que esquecido para soar e aparecer de modo renovado, inédito e surpreendente, inclusive para o próprio executante. É assim que, muitas vezes, o resultado do improviso costuma ser atribuído a uma inspiração divina, de modo semelhante ao sentido espiritual emprestado por Clarice à impressão total de um cavalo.

Improvisar é assim uma questão de movimento, rápido ou lento, mas sempre em sintonia com o evento que desperta a reação concomitante e simultânea, de modo que o percebido seja já o pensado e o que se está dizendo e sendo lido: "Como que estou escrevendo na hora mesma em que sou lido". ${ }^{0}$ Nessa sentença magnífica, Lispector sintetiza o que será a marca de seus últimos escritos: textos em fragmentos, posteriormente unidos e retrabalhados, mas sem perder o frescor, a vividez e a imediatez do vivido. É aqui que a improvisação passa a ser mais e mais citada em seus textos, juntamente com a concepção da escrita de ouvido. Seguindo essa orientacão, sugiro então definir improvisação como um ato de alcançar um estado ideal, no qual a impressão (sensória, física, corporal) seja já a expressão (simbólica e artística), de modo que não haja (utopicamente) separação entre o ver e o pintado, o dizer e o escrito, o ouvido e o ruído.

\section{A hora da estrela}

Passo agora a mostrar como a multiplicação de vozes na narrativa se relaciona com a improvisação e a escrita de ouvido. Em $A$ hora da estrela, Lispector se metamorfoseia em Rodrigo S. M., apresentado como o autor do livro sobre a personagem Macabéa, uma pobre imigrante do Nordeste do Brasil, vivendo na cidade do Rio de Janeiro onde, semianalfabeta, trabalha como datilógrafa. Sabendo que Lispector também viveu no Nordeste e emigrou para o Rio de Janeiro, a verdadeira autora passa a situar-se no meio: entre o autor masculino fictício que ocupa seu lugar (Rodrigo S. M.) e a personagem Macabéa, cujo nome remete à sua origem judaica (remissão aos macabeus).

Assim, em seu último livro publicado em vida, Clarice mescla sua origem judaicoucraniana à vida nordestina de uma Macabéa qualquer. Fazendo isso, ela mistura ecos do ídiche de sua infância ${ }^{51}$ aos ecos dos sons do Nordeste brasileiro, ao compor um livro que tem como um de seus treze subtítulos: "cordel lacrimogêneo". O livro todo, aliás, se produz como uma escrita em eco, em que ressoam dissonantes Bach e o som do radio-relógio, o texto do autor masculino e a voz feminina. Estabalece-se assim entre Lispector e Rodrigo S. M. uma dupla voz para falar melhor de uma personagem sem voz ("ela falava, sim, mas era extremamente muda" ${ }^{52}$ ), que tem ou deveria ter o direito ao grito (outro subtítulo do livro).

Esse procedimento de duplicação autoral, também se repete em Água viva, ${ }^{53}$ com a personagem pintora que se transforma na escritora do texto que lemos. O mesmo ocorre no livro póstumo Um sopro de vida, que estabelece o jogo entre o Autor (novamente masculino) e a personagem Ângela, ela também escritora. ${ }^{54}$ Carlos Mendes de Sousa chamou a esse procedimento de "texto exposto" 55 , ou seja, livro que expõe os bastidores da criação, transposta 
para personagens escritores, que vivenciam e expressam os dilemas, angústias e delícias do escrever e do narrar. Essa mesma expressão, "texto exposto", aplica-se, como se verá, aos casos de Machado de Assis e Guimarães Rosa.

$\mathrm{Na}$ duplicação ou multiplicação de autores e vozes ressalta outra característica: a do texto que se constrói sem controle ou de improviso: "esta história não tem nenhuma técnica, nem de estilo, ela é ao deus-dará. [...] Durante o dia eu faço, como todos, gestos despercebidos por mim mesmo. Pois um dos gestos mais despercebidos é esta história de que não tenho culpa e sai como sair". ${ }^{56}$ A hora da estrela apresenta-se assim como um "livro inacabado",57 em processo de escritura, e toda a primeira parte é dedicada a uma autoexposição sobre a escrita do livro, como um ensaio metaficcional antes da ação da narrativa, que começa então de um salto: "O jeito é começar de repente assim como eu me lanço na água gélida do mar... Vou agora começar pelo meio dizendo que -" ${ }^{58}$. Em Lispector, a improvisação vai tão longe que remete não apenas a um método, mas a um "modo de vida". É o que encontramos em outra reflexão da própria Clarice sobre a liberdade na escrita: "A improvisação como modo de viver. Mesmo as narrativas discursivas têm em si uma liberdade, se não de quebra do condicionamento, mas de improvisação do destino". ${ }^{59} \mathrm{Ou}$ seja, nela, os enredos se estruturam fingindo não ter estrutura, como se se desenvolvessem ao acaso. ${ }^{60}$ Finalmente, esse processo em que a multiplicação de vozes se conjuga com o improviso é assim sintetizado na fala de Clarice/Ângela: "Por que Ângela é tão novidade e inusitada que eu me assusto. Me assusto em deslumbre e temor diante do seu improviso. Eu a imito? ou ela me imita? Não sei: mas o modo de escrever dela me lembra ferozmente o meu como um filho pode parecer com o pai". ${ }^{61}$

Veremos que em Machado de Assis e em Guimarães Rosa a escrita de ouvido juntamente com o improviso se manifesta em um encadeamento discursivo oblíquo, compondo uma lógica do sinuoso, tortuoso, e indireto, e que o improviso também está presente em textos que fingem estarem sendo escritos sem planejamento, aqui e agora, enquanto seus narradores conversam com os leitores.

\section{Machado de Assis e a auditividade}

Em Machado de Assis, a recorrência da duplicação do escritor em personagens que passam a assumir a função de autores, foi agudamente analisada por Abel Barros Baptista como a presença do que ele denomina "autores supostos" 62 , tais como Brás Cubas, personagem que escreve suas memórias do túmulo, no livro homônimo, Memórias póstumas de Brás Cubas, e Bento Santiago, o personagem que é o autor de Dom Casmurro. Há, em Dom Casmurro, uma série de marcas que anunciam ao leitor o fato do livro se escrever aqui e agora antes de ser impresso, como se o leitor acompanhasse o momento da criação: "Perdão, mas este capítulo devia ser precedido de outro, em que contasse um incidente [...], mas custa muito alterar o número das páginas; vai assim mesmo, depois a narraçao seguirá direita até o fim". 63 Bento Santiago é, assim, um "autor suposto", que finge estar escrevendo o livro enquanto o leitor o lê, o que o leva a defini-lo como um "livro falho" (cap. LIX) com lacunas a serem preenchidas pelos leitores.

Essas marcas foram analisadas por Baptista como chave do interesse mundial por Machado de Assis como um mestre do procedimento metaficcional que anuncia o que será a marca da "morte do autor" no século XX. O papel do escritor deixa de ser, primordialmente, o 
de escrever o texto, já que este é "escrito" por seus personagens, e passa a ter importância a escuta de outras vozes, criando assim uma "obra difusa" em uma "forma livre". Estes termos aparecem expressos pelo personagem Brás Cubas ao definir o seu livro: "Trata-se de uma obra difusa, na qual eu, Brás Cubas, se adotei a forma livre de um Sterne [...]". ${ }^{64}$ Como mostra Baptista, essa definição do livro é repetida pelo autor efetivo, Machado de Assis, que cita seu personagem como a voz de autoridade a definir o livro que é ou deveria ser propriedade do autor efetivo, aqui destituído de seu poder de voz única.

Essa forma "difusa", do livro que se espalha e se dispersa, pode também ser relacionada ao que diz Roland Barthes, no texto "Écoute", quando define a escuta moderna a partir do paradigma da escuta psicanalítica, atenta mais a ouvir nuances de fala e entonação do que à compreensão literal do significado das frases pronunciadas:

Ce qui est ecouté ici et là (principalement dans le champ de l'art, don't la fonction est
souvent utopiste), ce n'est pas la venue d'un signifié, objet d'une reconnaissance ou
d'un déchiffrement, c'est la dispersion même, le miroitement des signifiants, sans
cesse remis dans la course d'une écoute qui en produit sans cesse des nouveaux, san
jamais arreter le sens: ce phénomène de miroitement s'appele la signifiance (distincte
de la signification) [...] elle oblige le sujet à renoncer à son "intimité". 65

A meu ver, a obra difusa de Machado apela a uma escuta também ela difusa ou dispersa, que obriga o sujeito (autor ou leitor) a renunciar à sua intimidade para adentrar uma zona de sussuros e segredos coletivos inconscientes agora expostos e configurados. É aqui que a questão da escrita auditiva em Machado relaciona-se ao termo "auditividade" e a uma forma gestual, a um jeito de corpo, transcrito e mimetizado no jogo da escrita. Assim, Brás Cubas, que narra sua vida depois de morto, no além-túmulo, anuncia uma das marcas principais da auditividade em uma escrita sinuosa, que não segue o "estilo regular e fluente" prezado pelo leitor mas antes os gestos corporais: "[...] este livro e o meu estilo são como os ébrios, guinam à direita e à esquerda, andam e param, resmungam, urram, gargalham, ameaçam o céu, escorregam e caem...".66

\section{O "estilo de capoeira"}

Considero o termo "auditividade" (e sua ambivalência constitutiva, como se verá adiante) fundamental para se compreender os modos de elaboração peculiares à cultura letrada no Brasil. O termo foi proposto por Luiz Costa Lima, primeiro em um ensaio a respeito da situação histórica do intelectual no Brasil publicado nos anos $1980,{ }^{67}$ e depois revisto em um ensaio sobre Machado de Assis publicado na década de $1990 .{ }^{68}$ No primeiro texto, Costa Lima analisa, dos tempos coloniais ao século XIX, a situação do letrado atuando diante de uma população predominantemente iletrada, de um lado, e de outro, dominado por uma elite que sempre marginalizou ou rebaixou as práticas culturais negras, caboclas e indígenas. Nesse contexto, a presença do auditivo na escrita recebe uma conotação negativa, como a presença de uma oratória demagógica destinada à persuasão imediata do público, mais do que à elaboração de uma escrita voltada para o difícil labor do convencimento argumentativo e conceitual. No segundo texto, porém, o termo "auditividade" ganha conotações positivas, relacionadas à incorporação de práticas culturais afro-brasileiras na escrita literária. O exemplo, agora, é Machado de Assis. Na leitura de Costa Lima, o estilo das crônicas de Machado de Assis é 
marcado por um jogo de palavras que se esquivam, compondo uma dança intelectual que desnorteia o leitor, ao mesmo tempo que permite a Machado driblar possíveis censuras à sua visão dos acontecimentos políticos da época. A esse estilo enviesado, Costa Lima chama "estilo de capoeira", e a Machado, "mestre de capoeira", estabelecendo uma inédita relação entre a escrita literária e o jogo de corpo afro-brasileiro.

No insight de Costa Lima, "o auditivo machadiano inseria a ginga da capoeira na tinta traçada sobre a página", ${ }^{69}$, isto é, Machado escreveria com um jogo de palavras semelhante ao jogo de corpo marcado pelo drible e pelo negaceio. No texto escrito, o negaceio é criado "pelo desmantelo da lógica proposicional". ${ }^{70}$ Assim, ao invés de uma argumentaçao linear, tem-se um encadeamento de frases solto e constelacional, compondo uma "escrita impregnada de auditividade". Costa Lima então indaga: "Pode-se entender a capoeira como princípio de individuação de uma forma de escrita?". ${ }^{71}$ Diferente de uma reflexão fraca e inconsistente, o que se vê na alta elaboraçao poética de escritores como Machado de Assis é uma escrita que incorpora um outro encadeamento, uma conexão mais alusiva, cheia de meandros e nuances como uma auditividade consciente e experimentalmente praticada.

Assim, se Roberto Schwarz refere a volubilidade dos narradores machadianos como representação crítica da elite local, Costa Lima percebe o negaceio verbal nas crônicas de Machado como sendo paralelo a uma das formas mais populares de expressão corporal no Brasil, juntando-se, de outro modo, ao que diz José Miguel Wisnik em seu estudo sobre a presença do som do maxixe em Machado, através do qual este revelaria sua mulatice. ${ }^{72} \mathrm{~A}$ escrita de Machado possui diferentes modelos de inspiração, e a capoeira seria um dos componentes relacionados à "prática expressivo-comunicativa que ele capturou em seu próprio país". ${ }^{73}$ Para Costa Lima, como um componente interno, a capoeira como estilo, do ponto de vista de um nativo "é talvez o aspecto mais rico e mais complicado a ser descrito, porque ainda mesclado à nossa presença". ${ }^{74}$ Nesse sentido, aumenta a importância de ouvidos "estrangeiros" ou capazes de se distanciarem do local para perceber suas possíveis ressonâncias imprevistas. Diria, então, que o escritor dá voz em sua escrita à prática comunicativa que recebe do corpo coletivo do qual faz parte, e retransmite essa prática aos leitores que a captam nas entrelinhas do seu texto.

Por auditividade, entende-se, assim, além da presença da fala oral na escrita, um encadeamento de frases constelacional. Ao pensar a questão da "escrita de ouvido" a partir de Lispector, acrescento, pois, aos significados do termo "auditividade" mais um elemento: o auditivo significa também um modo de ouvir aquilo que a língua tem de mais íntimo e de mais difícil de ser apreendido e repetido: sua entonação e seus sotaques; e significa também a habilidade do escritor em conseguir transmitir por escrito essa sutil presença da voz e suas reverberações no texto.

\section{Guimarães Rosa e a escrita de guerrilha}

Se os "autores supostos" de Machado de Assis são personagens do Rio de Janeiro da segunda metade do século XIX, no escritor Guimarães Rosa, que representa o vasto espaço do interior do Brasil conhecido como "sertão", encontramos esse mesmo recurso de duplicação autoral. Em Grande sertão: veredas, de 1956, o personagem Riobaldo narra, em uma fala 
ininterrupta, sua vida ao doutor da cidade que o escuta. Temos assim um romance que expõe metaficcionalmente a formação de um autor oriundo de uma experiência oral. Riobaldo narra sua vida e supõe-se que o senhor que o visita esteja anotando o que seu informante sobre o sertão lhe conta, como fazia o próprio Guimarães Rosa em suas viagens de pesquisa. A situação assemelha-se, então, a uma escrita etnográfica fictícia, na qual o autor, Guimarães Rosa, ouve o que seu personagem lhe diz, fingindo também não ter controle quanto à ordem narrativa, que segue o vai-e-vem da oralidade.

Muito já foi dito e ainda há a se dizer sobre a oralidade na escrita de Guimarães Rosa, mas na análise da auditividade seria bom lembrar o episódio-chave de Maria Mutema, a personagem que mata pelo ouvido ${ }^{75}$ do mesmo modo que a fala ininterrupta de Riobaldo mata, silencia, a fala do doutor da cidade. O livro, aliás, começa ao som de um tiro: "Tiros que o sr. ouviu foram de briga de homem não", ${ }^{76}$ indicando que o leitor está entrando em um território discursivo perigoso. Se em Os sertões, Euclides da Cunha denunciou o crime da cidade sobre o sertão, em Rosa, o sertão começa atirando de modo a permanecer vivo e poder ser ouvido pelo homem da cidade. Grande sertão: veredas é assim uma máquina discursiva de guerrilha. Como os jagunços em guerra e como os rastreadores, a tática retórica de guerrilha usa as armas auditivas (fala, oralidade, escuta) para desarmar as armadilhas da escrita letrada quando esta cala ou fala no lugar dos iletrados.

Em Grande sertão: veredas, a estrutura do livro sem capítulos mimetiza uma fala improvisada que dura cerca de quinhentas páginas, e que parece seguir a esmo, sem controle. Como diz o narrador, sua fala "erra rumo", sem direção certa, exatamente porque não é como o senhor da cidade que sabe "compor estórias em livro". No entanto, o que parece improviso, como uma narrativa que finge que se constrói ao acaso, obedece a uma ordem, uma ordem desorganizada, digamos assim, mas nem por isso menos presente. Ou seja, por mimetizar a oralidade o improviso tem uma ordem não fixa, mas móvel, contingente e dependente da leitura que se fizer, privilegiando tais ou quais aspectos da estória. Cada leitor, então, a cada vez que quiser recontar a história com suas próprias palavras, organizará (ou desorganizará) o relato à sua maneira, apresentando-se o livro como um mar incontrolável (segundo uma das metáforas preferidas do relato sertanejo), sempre renovado a cada onda de leituras. Nesse sentido, retomando os termos de Machado de Assis, aqui também encontramos uma "obra difusa", escrita em uma "forma livre".

Além disso, Grande sertão: veredas é um romance que encena uma fala e uma escuta. Quem fala é Riobaldo, um jagunço aposentado, que conta o que foi sua vida. Quem ouve é o "doutor", um "senhor" da cidade que visita o sertão, e que permanece com Riobaldo por três dias. Se Riobaldo fala incessantemente, ele, no entanto, não é o dono da voz, não é porta-voz de nenhuma verdade e de nenhuma certeza. Sua experiência de vida não se pacifica num significado final, único, mas se problematiza numa pergunta. Ele fala do que não sabe, e conta para saber, na esperança de uma resposta.

Como a fala do doutor não aparece, o sentido da vida de Riobaldo não se esclarece, permanecendo como uma interrogação em busca de uma resposta. É assim que o romance não finaliza com o ponto final mas com o símbolo do infinito e, como o sertão, "se divulga", ultrapassa seu limite e aponta para fora. Nesse caso, a cena em que um fala e outro escuta é também a cena que se estabelece entre leitor e livro, entre a relação que a obra escrita, e 
portanto falante, estabelece com o leitor posto na situação de ouvinte. Mas a cena em que um fala e outro escuta também pode ser uma referência ao momento da elaboração da obra, podendo ser lida biograficamente. Sabe-se que Rosa viajava pelo sertão e anotava em cadernos as coisas que via e ouvia. Nesse caso, o doutor seria uma espécie de "alter-ego" do autor em suas viagens pelo sertão, e Riobaldo, a sua fonte e inspiração. No entanto, a situação pode ser ainda mais complexa. Se o escritor é, como diz Roland Barthes, aquele que ouve sua própria fala até encontrar a melhor variação para o tema, esse seria não o doutor, mas o próprio Riobaldo que fala e desfala, que conta e contesta seu próprio contar, em busca da melhor forma de expressão. ${ }^{77}$ É impossível também não pensar que a cena em que um fala e o outro ouve é a cena de origem da psicanálise, quando o inconsciente se faz ouvir. Numa última instância, mas que é também primeira, a enunciação em Grande sertão: veredas remeteria à cena do homem falando e interpelando Deus. Ou ainda, relembrando o episódio de Maria Mutema, podemos pensar em uma situação de confessionário.

\section{Coda}

$\mathrm{Na}$ duplicação ou multiplicação de autores e vozes ressalta pois, uma característica em comum entre as obras de Machado de Assis, Clarice Lispector e Guimarães Rosa, de outro modo tão distintas entre si: todas se apresentam como sendo escritas no momento mesmo em que são lidas, ou seja, como se estivessem sendo elaboradas aqui e agora, de improviso, sem um controle prévio de seus autores efetivos, que se tornam, digamos assim, tomados por sua própria escritura e assombrados por seus duplos, que os destituem do controle da autoria. $\mathrm{O}$ que me interessa ressaltar é que nessa filiação incontrolável, é a voz desses personagensautores supostos que guia a construção da narrativa, passando a ser o autor efetivo (Lispector, Rosa e Machado) não aquele que escreve, mas aquele que ouve, e segue a direção que a voz de seus personagens-autores indicam. O escritor, nesse sentido, atua como um etnógrafo que ouve sua própria cultura como se fosse estrangeiro a ela, estranhando-a para melhor inventá-la em suas ficções e dicções. Apesar da duplicação autoral ser um procedimento comum a muitas literaturas, o fato de que (pelo menos) três grandes nomes da literatura no Brasil a tenham praticado (penso no exemplo de outro escritor, Graciliano Ramos e seu personagem-autor Paulo Honório, de São Bernardo (1934)) pode confirmar a hipótese de que esse procedimento casa-se bem com uma tendência da expressão no Brasil marcada pela forte presença da oralidade e, por conseguinte, da auditividade. Daí a importância que assume a "escrita de ouvido" como marca distintiva (ou "auditiva") no cerne da literatura no Brasil.

\section{Referências bibliográficas}

BAPTISTA, Abel Barros, Autobibliografias: Solicitação do livro na ficção de Machado de Assis, Campinas, Editora Unicamp, 2003.

PÉCORA, Alcir "Vieira, o índio e o corpo místico" in Adauto Novaes (org.), Tempo e história, São Paulo, Companhia das Letras, 1994, p. 423-461. 


\section{Notas de fim}

${ }^{1}$ Este texto é a versão bastante ampliada e revista de artigo publicado em inglês sob o título "Writing by Ear: Clarice Lispector, Machado de Assis, Guimarães Rosa and the Mimesis of Improvisation", Critical Studies in Improvisation/ Etudes critiques en improvisation, University of Guelph, Canadá, vol. 7, no. 1: 2011, p. 1-10. Versões iniciais foram apresentadas nos congressos da Brasa, em Urbana-Champaign, Illinois, em setembro de 2012, e na Apsa, em Iowa City, em outubro de 2102. Gostaria de agradecer os valiosos comentârios recebidos de colegas e ouvintes em ambas as ocasiões. Condenso neste ensaio algumas diretrizes principais de um livro em andamento provisioriamente intitulado Echopoetics. Writing by Ear in Brazilian Literature.

${ }^{2}$ Caetano Veloso, "Sou seu sabiá" in Noites do norte, CD Universal, 2000.

${ }^{3}$ Clarice Lispector, A hora da estrela, Rio de Janeiro, Nova Fronteira, 1984, p. 25.

${ }^{4}$ Como explicita o título da série em que se inclui, "Stelegramas" (1975-1978), publicado em Viva vaia em 1979. In Augusto de Campos, Poesia, 1949-1979, Cotia: Ateliê Editorial, 2000.

5 Verso da canção "Sampa” de Caetano Veloso, Muito, Polygram LP 6349-382, 1978.

${ }^{6}$ Augusto de Campos, Despoesia, São Paulo, Perspectiva, 1994.

${ }^{7}$ Clarice Lispector, A hora da estrela, op. cit., p. 97.

${ }^{8}$ Clarice Lispector, Um sopro de vida: Pulsações, Rio de Janeiro, Nova Fronteira, 1978, p. 41.

9 Dentre a vasta e importante bibliografia sobre música e literatura no Brasil, ver os estudos de José Miguel Wisnik, Sem receita: Ensaios e canções, São Paulo, Publifolha, 2004; Luiz Tatit, O século da canção, Cotia, Ateliê Editorial, 2004; e Charles Perrone, Seven Faces: Brazilian Poetry Since Modernism, Durham, Duke University Press, 1996; Brazil, Lyric, and the Ämericas, Gainesville, University Press of Florida, 2010.

10 Para uma recente síntese dessa corrente teórica (que inclui Havelock, Ong, McLuhan e outros) ver texto de Anxo Abuín González ("Espaces acoustiques, textures sonores: Oralites tertiaires et langages électroniques", Recherche Littéraire, vol. 26, no. 51-52, verão 2010, p. 3-14), e para uma perspectiva do campo da musicologia ver o texto de Carolyn Abbate ("Music - Drastic or Gnostic?", Critical Inquiry, no. 30, primavera 2004, p. 505$36)$.

11 Ver Way Chee Dimock, "A Theory of Resonance”, PMLA, vol. 112, no. 5, 1997, p.1060-71.

12 Apesar de este estudo ter como foco a literatura produzida no Brasil, o objetivo é mais amplo: espera-se que o conceito de escrita de ouvido possa ser útil para estudos sobre literaturas produzidas na América Latina, no Caribe, na Africa e em outros contextos pós-coloniais.

13 Penso em qualidade no sentido proposto por Roland Barthes: "Ou'est-ce donc que la musique? [...] C'est une qualité de langage. Mais cette qualité de langage ne relève en rien des sciençes du language (poétique, rhétorique, sémiologique), car en devenant qualité, ce qui est promu dans le langage, c'ést cé qu'il ne dít pas, n'articule pas. [...]. La musique est à la fois l'exprimé et l'implicite du texte: ce qui est prononcé (soumis à inflexions) mais n' est pas articulé: ce qui est à la fois en dehors du sens et du non-sens, à plein dans cette significance, que la theorie du texte essaye aujourd'hui de postuler et de situer". Roland Barthes, "La Musique, la voix, la langue" in Oeuvres complètes, Tome V (1977-1980), Paris, Editions du Seuil, 2002, p. 528.

14 Apesar de não abordar a prosa de ficção contemporânea, a noção de escrita de ouvido pode ter ressonâncias nos trabalhos de escritores de prosa de ficção em atividade como Silviano Santiago, Veronica Stigger, Nuno Ramos, Marcelo Mirisola, Evandro de Affonso Ferreira e Ana Miranda, entre outros.

${ }^{15}$ Mary Louise Pratt, Imperial Eyes. Travel Writing and Transculturation, London, Routledge, 1992.

${ }^{16}$ Idem, p. 6, tradução minha.

17 David Toop, Sinister Resonance: The Mediumship of the Listener, Nova York, Continuum, 2010, p. 91, tradução minha.

18 Peter Sloterdjik, Bubbles. Spheres Vol. I: Microspherology, trad. Wieland Hoban, Nova York, Semiotext(e), 2011.

${ }^{19}$ Para uma análise filosófica da voz e do corpo materno, ver o excelente estudo das principais figuras literárias e mitológicas, por Adriana Cavarero, For. More Than One Voice. Toward a Philosophy of Vocal Expression, trad. Paul A. Kottman, Stanford, Stanford University Press, 2005.

20 Emily Apter, The Translation Zone. A New Comparative Literature, Princeton, Oxford, Princeton University Press, 2006.

${ }^{21}$ Veja-se o importante estudo de Jean-Luc Nancy, À L'Écoute, Paris, Galilée, 2002.

${ }^{22}$ Marcello Moreira aponta para a "audição dominante" na Colônia dentro de "um regime pragmático de forte oralidade" ao mesmo tempo em que aponta para o "emudecimento crescente de uma oralidade domesticada pela ação escritural" na produção de gramáticas pelos jesuítas. Marcello Moreira, "O rumor de uma língua quase sélvagem em diálogos catequéticos na América portuguesa" in Angel Marcos de Dios (org.), Aula Bilingue II: Uso del castellano y competencias plurilingües en el sistema literario peninsular. Salamanca, Luso-Española de Ediciones, 2013, vol. 1, pp. 161-176. Para um estudo mais detalhado, cf: Andrea Dahrer, A oralidade perdida. Ensaios de história das práticas letradas, Rio de Janeiro, Civilização Brasileira, 2012.

${ }^{23}$ Antônio Vieira, "Sermão do Espírito Santo" in Alcir Pécora (org.), Sermões, São Paulo, Hedra, 2000, p. 428-29. ${ }^{24}$ Alcir Pécora, "O bom selvagem e o boçal", Revista Lusófona de Ciências das Religiões, ano VII, no. 13/14, 2008, pp. 65-76, 70 .

25 A passagem encontra-se no "Manifesto antropófago": "Contra o Padre Vieira. Autor do nosso primeiro emprestimo, para ganhar comissão. O rei analfabeto dissera-lhe: ponha isso no papel mas sem muita lábia. Fez-se 
o empréstimo. Vieira deixou o dinheiro em Portugal e nos trouxe a lábia". Oswald de Andrade, "Manifesto antropófago" in A utopia antropofágica, São Paulo, Editora Globo, p. 69.

26 Oswald de Andrade, "Mensagem ao antropófago desconhecido" (1946) in Estética e política, São Paulo, Editora Globo, 1990, p. 285.

27 Oswald de Andrade, "O poeta do Nordeste" in Vera Maria Chalmers (estabelecimento de texto, introdução e notas), Telefonema, tese de livre-docência, DELL- Unicamp, 1993, p. 159.

28 Intitulado "Objeto e fim da presente obra", o prefácio foi publicado na Revista do Brasil. In Oswald de Andrade, Serafim Ponte Grande. $9^{a}$ ed., São Paulo, Globo, 2007, pp. 47-8.

${ }^{29}$ Lembro aqui brevemente dois outros "casos sonoros" de Oswald. No ensaio de Antonio Candido, uma revisão e balanço de seu relacionamento intelectual com Oswald, o crítico relembra quando O. A. nos anos 1940 queria se candidatar para uma vaga no Departmento de Filosofia da Universidade de São Paulo. Indagado por Candido sobre como ele responderia a alguma pergunta "pernóstica" da banca, por exemplo, o que ele tem a dizer sobre a ontologia existencialista. Oswald rebate: diria à banca que eles estão muito atrasados, que a questão hoje não é ontológica mas odontológica. Antonio Candido, "Digressão sentimental sobre Oswald de Andrade" in Vários escritos, 4 ed., São Paulo/ Rio de Janeiro, Duas Cidades/ Ouro sobre Azul, 2004, pp. 33-66. O mesmo jogo jocoso e sonoro fará com o pseudônimo Marxilar com o qual assina os artigos na Revista de Antropofagia (192829),

entre muitos outros possíveis exemplos.

30 "O Brasil imigrante começou por trás. Cópia. Arte amanhecida da Europa requentada ao sol das costas. [...] Transponho a vida. Não copio igualzinho. Nisso residiu o mestre equívọco naturalista. [...] Tudo em arte e descoberta e transposição". Oswald de Andrade, Serafim Ponte Grande, op. cit., p. 34.

${ }^{31}$ Ana Luiza Martins Costa, "Mundo escutado", Scripta, vol. 9, no. 17, 2005, p. 47-60.

32 João Guimarães Rosa, “Aletria e hermenêutica” in Tutaméia. Terceiras estórias, Rio de Janeiro, José Olympio, 1979 , p. 7.

33 Guimarães Rosa apud Günter Lorenz, "Diálogo com Guimarães Rosa" in Eduardo F. Coutinho (org.), Guimarães Rosa, Rio de Janeiro, Civilização Brasileira, 1983, p. 88.

34 Jacques Derrida,"Tímpano" in Margens da filosofia, Campinas, São Paulo, Papirus, 1991, p. 8.

${ }^{35}$ Clarice Lispector, A hora da estrela, op. cit., p. 32.

${ }^{36}$ Claire Varin, Langues de feu. Essai sur Clarice Lispector, Québec, Éditions Trois, 1990, p. 25.

${ }^{37}$ Idem, p. 69.

38 Clarice Lispector, A hora da estrela, op. cit., p. 80. A esse respeito ver o estudo de Gabriela Lírio Gurgel, $A$ procura da palavra no escuro. Uma análise da criação de uma linguagem na obra de Clarice Lispector, Rio de Janeiro, 7Letras, 2001.

39 Penso aqui na presença do cego no conto "Amor", de Laços de família, como um exemplo máximo da importância da cegueira na obra de Lispector. Sobre a visão em outros de seus escritọ, ver estudo de Regina Lúcia Pontieri, Clarice Lispector: Uma poética do olhar, São Paulo, Ateliê Editorial, 1999 A respeito de visionarismo e cegueira na arte, cf. texto de Eyal Peretz, Becoming Visionary: Brian De Palma's Cinematic Education of the Senses, Stanford, Stanford University Press, 2008.

${ }^{40}$ Clarice Lispector, $A$ hora da estrela, op. cit., p. 27

${ }^{41}$ Idem, p. 25.

42 Para um relato detalhado sobre os antecedentes da chegada da família de Lispector ao Brasil, ver a biografia de Benjamin Moser, Why This World: a Biography of Clarice Lispector. Oxford: Oxford University Press, 2009. [Edição brasileira: Clarice, trad. José Geraldo Couto, São Paulo, Cosac Naify, 2009.]

${ }^{43}$ Ao entrevistar a irmã mais velha de Lispector, Varin descobre que seus pais falavam ídiche em casa, língua que Clarice ouvia, mas nunca aprendeu, è que permaneceu, como seu judaísmo, como uma voz oculta, mas presente como ressonância em sua escrita. Claire Varin, Langues de feu, op. cit., p. 61 .

${ }^{44}$ Cf. comentário de Deleuze a partir de frase de Proust, em Contre Saint-Beuve: "Os belos livros estão escritos em uma espécie de lingua estrangeira”. Gilles Deleuze, Crítica e clínica, trad. Peter Pál Pelbart, São Paulo, Editora 34, 1997, p. 9.

${ }^{45}$ Clarice Lispector, Langues de feu, op. cit., p. 29-30.

${ }^{46}$ Para falar da pobreza "quando tudo era mais sóbrio e digno", o livro, "esta coisa aí" é dedicado a compositores: Schumann, Beethoven, Bạch, Chopin, Stravinsky, Strauss, Debussy, Marlos Nobre, Prokófiev, Carl Orff, Schoenberg, aos dodecafônicos, aos eletrônicos.

${ }^{47}$ Clarice Lispector, A cidade sitiada, Rio de Janeiro, Sabiá, 1971, p. 20.

48 Texto citado por Pontieri, Clarice Lispector, op. cit., p. 17.

${ }^{49}$ Clarice Lispector, A descoberta do mundo, Rio de Janeiro, Nova Fronteira, 1984, p. 134.

${ }^{50}$ Clarice Lispector, $A$ hora da estrela, op. cit., p. 18

51 Nelson Vieira identificou a semelhança da escrita de $A$ hora da estrela com o "estilo talmúdico" de composição. Nelson Vieira, "A expressão judaica na obra de Clarice Lispector", Remate de Males, no. 9, Campinas, 1989.

52 Clarice Lispector, A, hora da estrela, op. cit., p. 44.

${ }^{53}$ Clarice Lispector, Agua viva, Rio de Janeiro, Nova Fronteira, 1978.

${ }^{54}$ Neste último livro, mais um elemento ressalta: a presença da amiga e secretária, Olga Borelli, que, após a morte da escritora, coleta os fragmentos esparsos e faz a montagem de Um sopro de vida, contribuindo como mais uma voz a falar por e com Lispector. 
${ }^{55}$ Carlos Mendes de Sousa, Figuras da escrita, Portugal, Universidade do Minho, 2000, p. 347.

${ }^{56}$ Clarice Lispector, A hora da estrela, op. cit., p. 44.

${ }^{57}$ Idem, p. 8.

${ }^{58}$ Idem, p. 31

${ }^{59}$ Clarice Lispector citada por Olga Borelli, Clarice Lispector - Esboço para um possível retrato, Rio de Janeiro, Nova Fronteira, 1981, p. 44.

${ }^{60}$ Para uma ótima análise dos últimos livros de Lispector, veja-se o estudo de Sônia Roncador. A autora questiona a noção de improvisação aplịcada à elaboração dos textos dẹ Lispector, sobretudo a Agụa-viva, livro que resulta da dépuração de um manuscrito anterior chamado "Objeto gritante". No entanto, ela relaciona os últimos textos de Lispector à prática da crônica e à informalidade de uma conversa, assim como encontra neles se não uma unidade de acão, "uma continuidade de tema e tom". Sonia Roncador, Poéticas do empobrecimento: A escrita derradeira de Clarice, São Paulo, Annablume, 2002, p. 72. Eu penso a improvisação como um método exatamente relacionado produção de um tom e não como sinônimo de espontaneidade ou de texto publicado sem revisão.

${ }^{61}$ Clarice Lispector, Um sopro de vida, op. cit., p. 71.

62 Abel Barros Baptista, A formação do nome: Duas interrogações sobre Machado de Assis, Campinas, Editora Unicamp, 2003, p. 135.

${ }^{63}$ Machado de Assis, Dom Casmurro in Obra completa, vol. I Romances, Rio de Janeiro, Editora Nova Aguilar, 1986, p. 931.

${ }^{64}$ Machado de Assis, Memórias póstumas de Brás Cubas in Obra completa, vol. I Romances, op. cit., p. 513.

${ }^{65}$ Roland Barthes. "Écoute" in Oeuvres complètes, Tome V (1977-1980), op. cit., p. 351, grifo meu.

${ }^{66}$ Machado de Assis, Memórias póstumas de Brás Cubas, op. cit., p. 583.

${ }^{67}$ Luiz Costa Lima, "Da existência precária: O sistema intelectual no Brasil” in Dispersa demanda: Ensaios sobre literatura e teoria, Rio de Janeiro, Francisco Alves, 1981.

${ }^{68}$ Luiz Costa Lima, "Machado: Mestre de capoeira” in Intervenções, São Paulo, Edusp, 2002.

${ }^{69}$ Luiz Costa Lima, "Machado: Mestre de capoeira”, op. cit., p. 335.

${ }^{70}$ Idem, p. 332

${ }^{71}$ Idem, p. 331

72 José Miguel Wisnik, "Machado maxixe: O caso Pestana” in Sem receita: Ensaios e canções, São Paulo, Publifolha, 2004

73 Idem, p. 339.

${ }^{74}$ Idem, ibidem.

75 Cf. o estudo de Walnice Nogueira Galvão, As formas do falso: Um estudo sobre a ambiguidade no Grande sertão: veredas, São Paulo, Perspectiva, 1972.

76 João Guimarães Rosa, Grande sertão: veredas, 6 ${ }^{\text {a }}$ ed., Rio de Janeiro, José Olympio, 1968, p. 3. 77 Cf. Barthes: “O escritor é pois um homem para quem falar é imediatamente escutar sua própria fala: assim se constitui uma fala recebida (embora ela seja criada), que é a própria literatura”. Roland Barthes, Crítica e verdade, trad. Leyla Perrone-Moisés, São Paulo, Perspectiva, 1970, p. 20. 